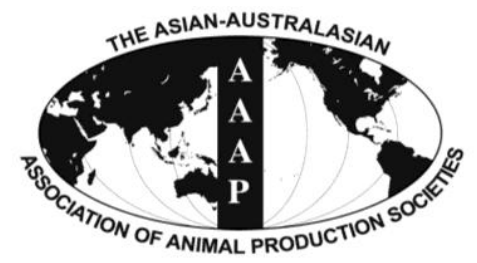

Asian Australas. J. Anim. Sci.

Vol. 26, No. 6 : 886-895 June 2013

http://dx.doi.org/10.5713/ajas.2012.12671

www.ajas.info

pISSN $1011-2367$ elSSN 1976-5517

\title{
Guava (Psidium guajava L.) Powder as an Antioxidant Dietary Fibre in Sheep Meat Nuggets
}

\author{
Arun K. Verma, V. Rajkumar, Rituparna Banerjee ${ }^{1}$, S. Biswas² and Arun K. Das* \\ Goat Products Technology Laboratory, Central Institute for Research on Goats, \\ Makhdoom, Farah-281122, Mathura, India
}

\begin{abstract}
This study was conducted to explore the antioxidant potential and functional value of guava (Psidium guajava L.) powder in muscle foods. Guava powder was used as a source of antioxidant dietary fibre in sheep meat nuggets at two different levels i.e., $0.5 \%$ (Treatment I) and $1.0 \%$ (Treatment II) and its effect was evaluated against control. Guava powder is rich in dietary fibre $(43.21 \%)$, phenolics (44.04 mg GAE/g) and possesses good radical scavenging activity as well as reducing power. Incorporation of guava powder resulted in significant decrease $(\mathrm{p}<0.05)$ in $\mathrm{pH}$ of emulsion and nuggets, emulsion stability, cooking yield and moisture content of nuggets while ash and moisture content of emulsion were increased. Total phenolics, total dietary fibre (TDF) and ash content significantly increased $(\mathrm{p}<0.05)$ in nuggets with added guava powder. Product redness value was significantly improved $(\mathrm{p}<0.05)$ due to guava powder. Textural properties did not differ significantly except, springiness and shear force values. Guava powder was found to retard lipid peroxidation of cooked sheep meat nuggets as measured by TBARS number during refrigerated storage. Guava powder did not affect sensory characteristics of the products and can be used as source of antioxidant dietary fibre in meat foods. (Key Words: Sheep Meat, Nuggets, Guava Powder, Antioxidant, Dietary Fibre, Meat Quality)
\end{abstract}

\section{INTRODUCTION}

In developing countries like India rapid urbanization, industrialization, globalization as well as increasing number of women workforce have been a driving factor for rapid inclination towards fast and convenient meat and food products. Many of these foods including meat products lack minimum amounts of dietary fibre (Verma and Banerjee, 2010) to fulfill the recommended dietary intake. Various reports in the past have revealed that intake of adequate dietary fibre is associated with the reduced risk of a range of chronic diseases; including colon cancer, obesity, cardiovascular diseases, and several other disorders (Eastwood, 1992; Johnson and Southgate, 1994). Research findings also reveal that a diet high in fibre generally promotes a healthier life style (Kritchevsky, 2000) and fibre intake can be viewed as a marker of healthy diet. Apart

\footnotetext{
* Corresponding Author: Arun K. Das. Tel: +91-565-2763380, Fax: +91-565-2763246, E-mail: arunlpt@gmail.com

${ }^{1}$ Department of Livestock Products Technology, NVC, Nagpur, 440006, India.

2 Department of Animal Products Technology \& Marketing, WBUAFS, Kolkata-37, India.

Submitted Dec. 4, 2012; Accepted Jan. 29, 2013; Revised Mar. 3, 2013
}

from physiological and health values incorporation of dietary fibre in meat products have many technological importance, as it affects water and fat binding capacity of emulsion, flavour, texture and colour of the meat products.

Lipid oxidation can have negative effects on the quality of meat and meat products resulting in changes in sensory attributes (colour, texture, odour, and flavour) and nutritional quality. Oxidation of unsaturated lipids in cooked meat during storage and reheating leads to the formation of stale or rancid flavour termed as warmed-over flavour (WOF) (Sato and Hegarty, 1971). Apart from lipid, oxidative processes in meat also lead to the degradation of proteins which, in turn, contribute to the deterioration in flavour, texture and colour of displayed meat products (Decker et al., 1995). Therefore, delaying lipid and protein oxidation are highly relevant to maintain the quality of meat products for long period. Although synthetic additives have been widely used in the meat industry to inhibit both, the process of lipid oxidation and microbial growth, the trend is to decrease their use because of the growing concern among consumers about such chemical additives (Chastain et al., 1982; Chen et al., 1984). Consequently, search for natural additives, especially of plant origin, has notably increased. Epidemiological studies have also indicated that frequent 
consumption of natural antioxidants is associated with a lower risk of cardiovascular disease and cancer (Renaud et al., 1998; Temple, 2000). The defensive effects of natural antioxidants in fruits and vegetables are related to three major groups: vitamins, phenolics, and carotenoids. Ascorbic acid and phenolics are known as hydrophilic antioxidants, while carotenoids are known as lipophilic antioxidants (Halliwell, 1996).

Attempts have been made to enrich the dietary fibre content in meat products using various ingredients such as oat fibre (Claus and Hunt, 1991), peach fibre (Griguelmo Miguel et al., 1999), apple pulp, chickpea hull flour (Verma et al., 2010; Verma et al., 2012), oat bran (Y1lmaz and Dağlıŏlu, 2003) and rice bran as well as different fibres (Huang et al., 2005; Huang et al., 2011). However the use of ingredients that are a source of dietary fibre besides having antioxidant potential could be very valuable as for as improvement of meat product quality and storage stability as well as promotion of consumer health is concerned. The function of natural antioxidants and dietary fibre in foods and biological systems has received much attention. The presence of polyphenols (PP) and carotenoids associated with dietary fibre may significantly affect the physiological properties and health effects of dietary fibre (Saura-Calixto, 2011). Fruits and vegetables play a significant role in the human diet and health by providing protection against cellular damage caused by exposure to high levels of free radicals (Dillard and German, 2000), while also aiding digestion. This is attributed to the fact that these foods provide an optimal mix of antioxidants such as vitamin $\mathrm{C}$ and E, polyphenols, carotenoids, and complex carbohydrates (Mahattanatawee et al., 2006).

Guava (Psidium guajava L.), now being recognized as "super food" is getting very much attention in the agro-food business due to the attractive characteristics of the fruit, such as health promoting bioactive components, functional elements. The fruit is considered as highly nutritious because it contains a high level of ascorbic acid (50-300 $\mathrm{mg} / 100 \mathrm{~g}$ fresh weight) and has several carotenoids such as phytofluene, $\beta$-carotene, $\beta$-cryptoxanthin, $\gamma$-carotene, lycopene, rubixanthin, cryptoflavin, lutein, and neochrome (Mercadante et al., 1999). Phenolic compounds such as myricetin and apigenin (Miean and Mohamed, 2001), ellagic acid, and anthocyanins (Misra and Seshadri, 1968) are also at high levels in guava fruits. Incorporation of fruits having several bioactive components, like guava in meat products would definitely enhance their physiological, functional and nutritional values. Till now there are no reports in the literature regarding use of guava in the meat products either as antioxidant or as a source of dietary fibre. Thus the present study reports the application of guava powder as a source of antioxidant dietary fibre in sheep meat nuggets and its effect on the various physicochemical, colour, textural and sensory characteristics of the product.

\section{MATERIALS AND METHODS}

\section{Raw materials}

Sheep meat was obtained from the Experimental Slaughter House of Institute for Research. It was packed in LDPE bags and kept under frozen storage at $-18^{\circ} \mathrm{C}$ till the product processing. The meat was cut into small cubes after partial thawing for $15 \mathrm{~h}$ at $4^{\circ} \mathrm{C}$ and minced with meat grinder (Tallers Ramon, Model P-22, Barcelona) using 10 $\mathrm{mm}$ followed by $5 \mathrm{~mm}$ plates. This ground sheep meat was used in different product formulations. Unripen white guava was procured from the market. After careful washing, these were sliced into small pieces (with peel on) and dried in a hot air oven at $55^{\circ} \mathrm{C}$. Dried guava was ground in a mixer in the form of powder and packed in a LDPE for further use. This powder was extracted (100 g) successively with 600 $\mathrm{ml}$ of water in a Soxhlet extractor for 18 to $20 \mathrm{~h}$. The extract was concentrated to dryness under reduced pressure and controlled temperature $\left(40\right.$ to $\left.50^{\circ} \mathrm{C}\right)$. The extract was prepared in duplicate and all analysis was carried out in triplicates.

\section{Detailed study}

In the present study physicochemical properties (proximate composition, soluble, insoluble and total dietary fibre) and antioxidant potential (total phenolics, radical scavenging activity and ferric reducing antioxidant power) of guava powder were evaluated. Guava powder was incorporated in sheep meat nuggets at two different levels i.e., $0.5 \%$ (Treatment I) and $1.0 \%$ (Treatment II). Physicochemical, colour, textural and sensory properties of these products was determined against the product prepared without guava powder (Control). Formulations of control and different treatments are presented in Table 1.

Table 1. Formulation of sheep meat nuggets with guava powder

\begin{tabular}{lccc}
\hline Ingredients & Control & Treatment I & Treatment II \\
\hline Meat & 72.09 & 71.59 & 71.09 \\
Salt & 1.5 & 1.5 & 1.5 \\
Polyphosphate & 0.5 & 0.5 & 0.5 \\
Sucrose & 0.3 & 0.3 & 0.3 \\
Nitrite & 0.015 & 0.015 & 0.015 \\
Ice flakes & 10 & 10 & 10 \\
Oil & 7 & 7 & 7 \\
Condiments & 4 & 4 & 4 \\
Guava powder & 0 & 0.5 & 1 \\
Maida & 3 & 3 & 3 \\
Spice mix & 1.6 & 1.6 & 1.6 \\
\hline
\end{tabular}

Control $=$ Sheep meat nuggets without guava powder.

Treatment $\mathrm{I}=$ Sheep meat nuggets with $0.5 \%$ guava powder.

Treatment II = Sheep meat nuggets with $1.0 \%$ guava powder 


\section{Preparation of nuggets}

Meat batter was prepared in a bowl chopper (Seydelmann K20, Ras, Germany). In a minced meat, required amount of sodium chloride, polyphosphate, sodium nitrite and sucrose was added and chopped for 2 to 3 min. After addition of ice flakes it was chopped again for 2 min. Thereafter, vegetable oil was added with continuous chopping followed by incorporation of condiment, guava powder, refined wheat flour and spice mix. Chopping ended after formation of uniform batter mix. Meat emulsion ( 650 g) was placed into stainless steel moulds $(18 \times 12 \times 4 \mathrm{~cm})$, packed compactly and covered. The emulsion filled moulds from all the treatments were clipped and cooked in a steam oven without pressure for $35 \mathrm{~min}$. The internal temperature of the cooked meat blocks $\left(90 \pm 1^{\circ} \mathrm{C}\right)$ was measured using a probe type thermometer (Fisher Scientific, USA). The meat blocks were cooled to room temperature, chilled overnight at $4 \pm 1{ }^{\circ} \mathrm{C}$ and cut into slices of $15 \mathrm{~mm}$ thickness using a meat slicer (Electrolux, Model H 300, Italy). The slices were manually cut into nuggets. About $200 \mathrm{~g}$ nuggets in each LDPE pouches were packed using a Roschermatic packaging machine (Roscher Geba, Germany) for further study. For the evaluation of antioxidant activity of guava powder during refrigerated storage, sheep meat nuggets were prepared with $0.1 \%$ BHT (BHT Nuggets), with guava powder $(0.5 \%$ and $1 \%)$ and without powder (control). These nuggets were stored at $4{ }^{\circ} \mathrm{C}$ for $15 \mathrm{~d}$ and analyzed for thiobarbituric acid reactive substances (TBARS) number. The experiment was replicated thrice.

\section{Product analyses}

Determination of total phenolics: The concentration of phenolic compounds in the guava powder extracts was determined by the Folin-Ciocalteau method as described by Singleton and Rossi (1965). In a $100 \mu$ l of different dilutions of extract, $0.75 \mathrm{ml}$ of Folin-Ciocalteau reagent was added and final volume was made ten times with distilled water. After $5 \mathrm{~min}, 0.75 \mathrm{ml}$ of a sodium carbonate solution $(7.5 \%)$ was added to each tube. The tubes were incubated for $90 \mathrm{~min}$ at room temperature in dark and the absorbance was determined spectrophotometrically (Hitachi, U-28000 Spectrophotometer, Tokyo, Japan) against a reagent blank at $725 \mathrm{~nm}$. A standard curve was plotted using different concentrations of gallic acid, and the amount of total phenolics was calculated as gallic acid equivalents (GAE) in mg/g of dried powder. Total phenolics in cooked sheep meat nuggets was analyzed by using the FolinCiocalteus (F-C) assay (Escarpa and González, 2001) with slight modifications. Five gram of cooked product was homogenized with $25 \mathrm{ml}$ of $70 \%$ acetone and kept overnight for extraction at refrigeration temperature. Suitable aliquots of extracts were taken in a test tube and the volume was made to $0.5 \mathrm{ml}$ with distilled water followed by the addition of $0.25 \mathrm{ml} \mathrm{F-C}(1 \mathrm{~N})$ reagent and $1.25 \mathrm{ml}$ sodium carbonate solution $(20 \%)$. The tubes were vortex mixed and the absorbance recorded at $725 \mathrm{~nm}$ after 40 min.

Radical scavenging activity using DPPH assay: The DPPH assay was performed according to the method of Fargere et al. (1995). An aliquot of the various concentrations of extract was mixed with $3 \mathrm{ml}$ of 2, 2diphenyl-1-picrylhydrazyl in methanol (final concentration of $250 \mu \mathrm{M}$ ) and the mixture was vortexed vigorously. The tubes were then incubated at room temperature for $30 \mathrm{~min}$ in the dark, and the absorbance was taken at $517 \mathrm{~nm}$. The radical scavenging activity (RSA) was calculated by the following equation:

$$
\begin{aligned}
& \operatorname{RSA}(\%)=\left(\text { Absorbance }_{\text {Control}^{-}} \text {Absorbance }_{\text {Sample }} /\right. \\
& \text { Absorbance } \left._{\text {Control }}\right) \times 100
\end{aligned}
$$

Ferric reducing antioxidant power (FRAP): The reducing power of the extracts was determined according to the method of Oyaizu (1986). Different concentrations of guava powder extract were mixed with $2.5 \mathrm{ml}$ of phosphate buffer $(0.2 \mathrm{M}, \mathrm{pH} 6.6)$ and $2.5 \mathrm{ml}$ of $1 \%(\mathrm{w} / \mathrm{v})$ potassium ferricyanide in $10 \mathrm{ml}$ test tubes. The mixtures were incubated for $20 \mathrm{~min}$ at $50^{\circ} \mathrm{C}$ followed by addition of $2.5 \mathrm{ml}$ of $10 \%$ trichloroacetic acid and then centrifugation at $700 \mathrm{~g}$ for $10 \mathrm{~min}$. The supernatant $(2.5 \mathrm{ml})$ was mixed with $2.5 \mathrm{ml}$ distilled water and $0.5 \mathrm{ml}$ of ferric chloride $(0.1 \% \mathrm{w} / \mathrm{v})$, and the absorbance was measured at $700 \mathrm{~nm}$ (Hitachi, U-28000 Spectrophotometer, Tokyo, Japan). Increase in absorbance of the reaction mixture indicated the reducing power of the sample.

pH, emulsion stability (ES) and cooking yield: The $\mathrm{pH}$ of the emulsion and nuggets was determined by blending 10 $\mathrm{g}$ sample with $50 \mathrm{ml}$ distilled water for a minute in a homogenizer (Model PT-MR-2100, Kinematica AG, Switzerland). The $\mathrm{pH}$ values were measured using a standardized electrode attached to a digital $\mathrm{pH}$ meter (Systronics, $\mu \mathrm{pH}$ system 361, Delhi, India). Emulsion stability percent of the samples was estimated by heating approximately $25 \mathrm{~g}$ of emulsion in a polypropylene bag at $80^{\circ} \mathrm{C}$ for 20 min using a thermostatically controlled water bath. After draining out the exudate, the cooked mass was cooled and weighed. Product yield was determined by recording the weight of each meat block before and after cooking. The yield was calculated and expressed as percentage by weight of cooked meat block/ weight of raw meat block $\times 100$.

Proximate analysis, dietary fibre and expressible water: The moisture, protein, fat and ash content of guava powder, emulsion and cooked goat meat nuggets as well as dietary fibre in guava powder and meat product were determined by the methods of AOAC (1995). Expressible water was 
estimated as per the procedure followed by Das and Sharma (2009). Briefly, about $5 \mathrm{~g}$ cooked samples were weighed and put between two layers of Whatman No. 1 filter paper. The samples were placed at the bottom of the $50 \mathrm{ml}$ centrifuge tubes and centrifuged at 1,500 g (Biofuge Primo R, Heraeus, Germany) for $15 \mathrm{~min}$. Immediately after centrifugation, the meat samples were re-weighed and the amount of expressible water was calculated as initial weight - final weight/ initial weight $\times 100$.

Texture profile analysis (TPA): Textural properties of nuggets were evaluated using the texturometer (Stable Micro System Model TA.XT 2i/25). TPA (Bourne, 1978) was performed using central cores of three pieces of each sample $\left(1.5 \mathrm{~cm}^{3}\right)$ which were compressed twice to $80 \%$ of the original height. A crosshead speed of $2 \mathrm{~mm} / \mathrm{s}$ was used. Shear force $\left(\mathrm{N} / \mathrm{cm}^{2}\right)$ and work of shearing (Ns) of samples were estimated with a Warner-Bratzler blade attached to the same texture analyzer. Three cores $\left(1.5 \mathrm{~cm}^{3}\right)$ were taken from nuggets of each treatment. The crosshead speed was 2 $\mathrm{mm} / \mathrm{s}$. Maximum force required to cut the sample (shear force) and the work needed to move the blade through the samples (work of shearing) were recorded.

Instrumental colour value: The colour parameter of the product was monitored by evaluating Hunter ' $L$ ', ' $a$ ' and ' $b$ ' values using ColorTec PCM+ (ColorTec Associates Inc., Clinton, NJ, USA). Hunter L (lightness), a (redness) and b (yellowness) values were measured on the outer surface of sheep nuggets from three randomly chosen spots.

Thiobarbituric acid reactive substances (TBRAS) number: Lipid oxidization in the goat meat patties was monitored by measuring thiobarbituric acid reactive substances at an interval of $5 \mathrm{~d}$ during refrigerated storage. The TBARS number (mg malonaldehyde $/ \mathrm{kg}$ ) of the sheep meat nuggets was determined using the extraction method described by Witte et al. (1970) with slight modifications, as the slurry was centrifuged at $3000 \mathrm{~g}$ for $10 \mathrm{~min}$ (Biofuge Primo R, Heraeus, Germany) instead of filtration through Whatman No. 42.

Sensory evaluation: A ten member experienced panelists evaluated sheep meat nuggets using 8 points descriptive scale (Keeton, 1983) where eight (8) denoted extremely desirable and one (1) denoted extremely poor. The panelists were informed about the nature of experiments without disclosing the identity of samples and were asked to evaluate the samples on the sensory evaluation proforma for appearance, flavour, juiciness, texture and overall acceptability. Samples were warmed using microwave oven for $1 \mathrm{~min}$ and served randomly to the panelists on plates. The panelists were provided filtered water to rinse mouth between samples.

\section{Statistical analysis}

Three independent experimental trials of the study were conducted and all experiments were carried out with triplicate sample analysis. Mean values for various parameters were calculated and were analyzed by one-way ANOVA using the SPSS software for windows (version 14.0). Storage data of TBARS number were analyzed using two-way ANOVA with treatment and storage time as main effects. Statistical significance was identified at the $95 \%$ confidence level $(p<0.05)$. The values were presented as mean along with standard error (Mean \pm Standard Error).

\section{RESULTS AND DISCUSSION}

\section{Properties of guava powder}

Proximate composition, dietary fibre: Proximate analysis of the guava powder is presented in Table 2. The moisture, protein, fat and ash in the guava powder were found to be $6.41,5.13,4.32$ and $5.04 \%$, respectively. Guava powder is rich in dietary fibre content and contained $43.21 \%$ total dietary fibre which is mostly contributed by insoluble dietary fibre $(98.4 \%)$. The dietary fibre content in the present study is in agreement with the findings of Jimenez-Escrig et al. (2001) who reported insoluble, soluble and total dietary fibre content in dried guava as 46.72 to $47.65 \%, 1.77$ to $1.83 \%$ and 48.55 to $49.42 \%$, respectively. According to them peel and pulp of Psidium guajava fruit has high levels of dietary fibre, indigestible fraction, and phenolic compounds. Nahar et al. (1990) found a similar relative value for insoluble dietary fibre $(91 \%$ of total dietary fibre) in the edible portion of Psidium guajava. The minor fraction in the samples was soluble dietary fibre (3 to $4 \%$ of total dietary fibre).

Total phenolics: Phenolic constitutes one of the major groups of compounds acting as primary antioxidants or free radical terminators. Determination of total phenolics is one of the important parameters to estimate the amount of antioxidants. Guava powder is rich in phenolic compounds which act as natural antioxidants. Total phenolics in guava powder were found to be $44.04 \mathrm{mgGAE}$ per gram (Table 2). The total phenolics (on fresh mass basis) was $344.9 \mathrm{mg}$ GAE/100 $\mathrm{g}$ in 'Allahabad Safeda' and ranged from 170.0 to $300.8 \mathrm{mg}$ GAE/100 $\mathrm{g}$ in the pink pulp clones (Thaipong et

Table 2. Proximate analysis and total phenolics in guava powder

\begin{tabular}{lr}
\hline Parameter & Amount \\
\hline Moisture (\%) & $6.41 \pm 0.11$ \\
Protein $(\%)$ & $5.13 \pm 0.26$ \\
Fat $(\%)$ & $4.32 \pm 0.24$ \\
Ash (\%) & $5.04 \pm 0.39$ \\
Insoluble dietary fibre $(\%)$ & $42.56 \pm 0.06$ \\
Soluble dietary fibre $(\%)$ & $0.65 \pm 0.04$ \\
Total dietary fibre $(\%)$ & $43.21 \pm 0.09$ \\
Total phenolics $(\mathrm{mgGAE} / \mathrm{g})$ & $44.04 \pm 0.56$ \\
\hline
\end{tabular}

GAE $=$ Gallic acid equivalent. 
al., 2006). According to Corrêa et al. (2011) total phenolics, expressed as equivalent of gallic acid (GAE), varied from 158 to $447 \mathrm{mg} \mathrm{GAE} / 100 \mathrm{~g}$ in guava. Luximon-Ramma et al. (2003) have reported that white pulp guava had higher antioxidant activity and total phenolics than pink pulp guava in which the antioxidant activity was 142.6 and 72.2 $\mathrm{mg} / 100 \mathrm{~g}$ in white and pink pulp, respectively, and the total phenolics was 247.3 and $126.4 \mathrm{mg} \mathrm{GAE} / 100 \mathrm{~g}$ in white and pink pulp, respectively.

DPPH radical scavenging activity: Radical scavenging activity (RSA) of guava powder extract is depicted in Figure 1. Guava powder extract showed concentration based scavenging activity. The DPPH radical has been widely used to test the free radical scavenging ability of various natural products and has been accepted as a model compound for free radicals originating in lipids (Da Porto et al., 2000). Free radicals are molecules that are present in the environment and also occur in the body as a natural part of physiological functions. They can cause cell damage, however, and when present in high levels, may contribute to chronic conditions such as cancer, diabetes, and heart disease. Guava fruit has very good nutritional value and it is rich in yellow carotenoid and ascorbic acid. Jiménez-Escrig et al. (2000) showed that the DPPH radical can be scavenged by carotenoids. The DPPH free radical scavenging by antioxidants is due to their hydrogen donating ability; the more the number of hydroxyl groups, the higher the possibility of free radical scavenging ability (Chen and Ho, 1995). A linear correlation between radical scavenging activity and polyphenolic content has been reported in an extensive range of vegetables and fruits (Robards et al., 1999).

Ferric reducing antioxidant power: Ferric reduction antioxidant power showed increase in absorbance corresponding to the concentration of guava powder extract (Figure 2). The reducing power of a compound is related to its electron-transfer ability; therefore, the reducing capacity of a compound may serve as a significant indicator of its potential antioxidant activity. Amarowicz et al. (2004) observed a direct correlation between antioxidant activities

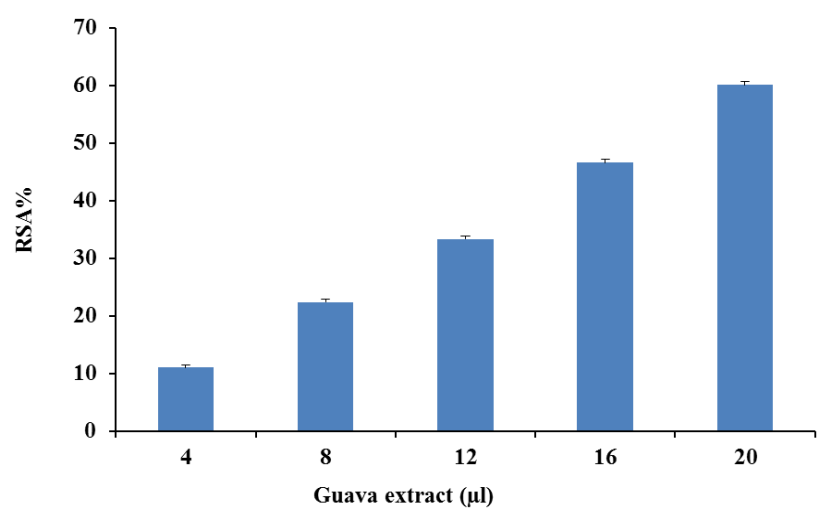

Figure 1. DPPH radical scavenging activity of guava extract.

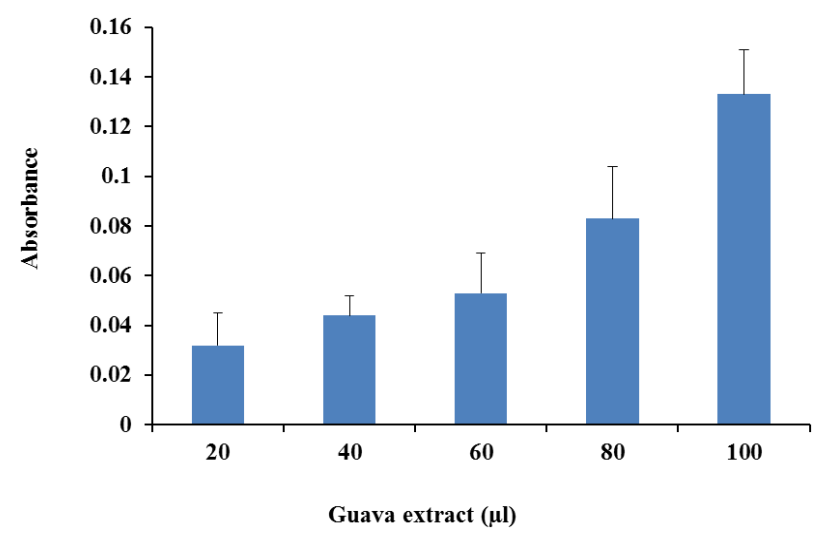

Figure 2. Ferric reduction antioxidant potential (FRAP) of guava extract.

and reducing power of certain plant extracts, which have been shown to exert antioxidant action by breaking the free radical chain through donation of hydrogen atom.

\section{Physicochemical properties of products}

The $\mathrm{pH}$ values of emulsion and sheep meat nuggets with guava powder were significantly lower $(p<0.05)$ than control (Table 3). This could be attributed to the added guava powder which is a good source of ascorbic acid. Guava (Psidium guajava L.) fruit contains a high level of ascorbic acid (50 to $300 \mathrm{mg} / 100 \mathrm{~g}$ fresh weight), which is three to six times higher than oranges (Mercadante et al., 1999). Incorporation of $1 \%$ guava powder significantly $(\mathrm{p}<0.05)$ decreased the emulsion stability. The probable reasons for the decreased emulsion stability due to guava inclusion could be lowering of the $\mathrm{pH}$ value of emulsion, poor fat binding capacity of guava powder and interference in the formation of uniform and stable emulsion.

Emulsion with $1 \%$ guava powder had significantly higher $(\mathrm{p}<0.05)$ moisture content as compared to control. This could be due to absorption of added water by the guava powder during emulsion preparation. Protein content among the emulsions did not differ significantly. Fat content in all the products did not differ significantly due to the same levels of added vegetable oil. Addition of guava powder significantly increased $(\mathrm{p}<0.05)$ the ash content in the emulsion. This could be due to higher ash content in added guava powder which represents mineral content in the fruit.

Cooking yield of the products containing guava powder was significantly lower $(\mathrm{p}<0.05)$ than the control. This could be due to formation of comparatively less stable emulsion for the formulations containing guava powder. Expressible water did not differ significantly $(p>0.05)$ among all the products. In contrast to the emulsion, moisture content in the product with guava powder $(1 \%)$ was significantly lower $(\mathrm{p}<0.05)$ than control. This could be due the loss of water/moisture, temporarily bound by the 
Table 3. Effect of guava powder on physicochemical properties of sheep meat nuggets

\begin{tabular}{|c|c|c|c|}
\hline Parameters & Control & Treatment I & Treatment II \\
\hline \multicolumn{4}{|l|}{ Emulsion } \\
\hline $\mathrm{pH}$ & $6.31 \pm 0.01^{\mathrm{a}}$ & $6.26 \pm 0.01^{\mathrm{b}}$ & $6.25 \pm 0.01^{\mathrm{b}}$ \\
\hline Emulsion stability (\%) & $92.02 \pm 0.30^{\mathrm{a}}$ & $90.74 \pm 0.62^{\mathrm{ab}}$ & $88.77 \pm 0.91^{\mathrm{b}}$ \\
\hline Moisture (\%) & $67.01 \pm 0.70^{\mathrm{b}}$ & $68.36 \pm 0.58^{\mathrm{ab}}$ & $69.41 \pm 0.95^{\mathrm{a}}$ \\
\hline Protein $(\%)$ & $12.53 \pm 0.14^{\mathrm{a}}$ & $12.45 \pm 0.35^{\mathrm{b}}$ & $12.32 \pm 0.29^{b}$ \\
\hline Fat $(\%)$ & $10.26 \pm 0.22$ & $10.08 \pm 0.07$ & $10.62 \pm 0.21$ \\
\hline $\operatorname{Ash}(\%)$ & $2.55 \pm 0.04^{\mathrm{b}}$ & $2.65 \pm 0.02^{\mathrm{a}}$ & $2.72 \pm 0.03^{\mathrm{a}}$ \\
\hline \multicolumn{4}{|l|}{ Nuggets } \\
\hline $\mathrm{pH}$ & $6.39 \pm 0.01^{\mathrm{a}}$ & $6.36 \pm 0.01^{\mathrm{b}}$ & $6.36 \pm 0.01^{\mathrm{b}}$ \\
\hline Cooking yield (\%) & $97.17 \pm 0.28^{\mathrm{a}}$ & $95.61 \pm 0.26^{\mathrm{b}}$ & $94.89 \pm 0.24^{\mathrm{b}}$ \\
\hline Expressible water $(\%)$ & $19.64 \pm 1.20$ & $21.03 \pm 1.03$ & $20.03 \pm 0.86$ \\
\hline Moisture (\%) & $67.42 \pm 0.38^{\mathrm{a}}$ & $67.98 \pm 0.24^{\mathrm{a}}$ & $66.49 \pm 0.15^{\mathrm{b}}$ \\
\hline Protein $(\%)$ & $15.25 \pm 0.58$ & $14.99 \pm 0.43$ & $14.83 \pm 0.35$ \\
\hline Fat $(\%)$ & $11.62 \pm 0.33$ & $11.97 \pm 0.19$ & $11.03 \pm 0.31$ \\
\hline Ash (\%) & $2.65 \pm 0.01^{\mathrm{b}}$ & $2.73 \pm 0.04^{\mathrm{a}}$ & $2.79 \pm 0.01^{\mathrm{a}}$ \\
\hline
\end{tabular}

Control $=$ Sheep meat nuggets without guava powder. Treatment $\mathrm{I}=$ Sheep meat nuggets with $0.5 \%$ guava powder.

Treatment II = Sheep meat nuggets with $1.0 \%$ guava powder. Means bearing different superscripts in a row differ significantly $(\mathrm{p}<0.05) ; \mathrm{n}=9$

guava powder during cooking. Guava powder used in the present study constitutes mainly insoluble dietary fibre which could not have retained moisture content during cooking. Additionally lower emulsion stability might have resulted in the loss of moisture content while cooking. Verma et al. (2012) reported significant decrease in moisture content of low salt, low fat chicken nuggets incorporated with chickpea hull flour. A decrease in moisture percent of low fat ground beef patties (Trout et al., 1992) and low fat dry fermented sausages (Mendoza et al., 2001) containing texture modifying ingredients and inulin, respectively have been observed. Yllmaz (2005) reported decrease in moisture content in low fat meatballs added with different levels of rye bran. Similar finding was also reported by Y1lmaz and Dağlıoğlu (2003) in meatballs with oat brans. Protein, fat and ash contents in the products showed similar trend to the emulsion.

Incorporation of guava powder in the formulation significantly increased $(p<0.05)$ the total dietary fibre

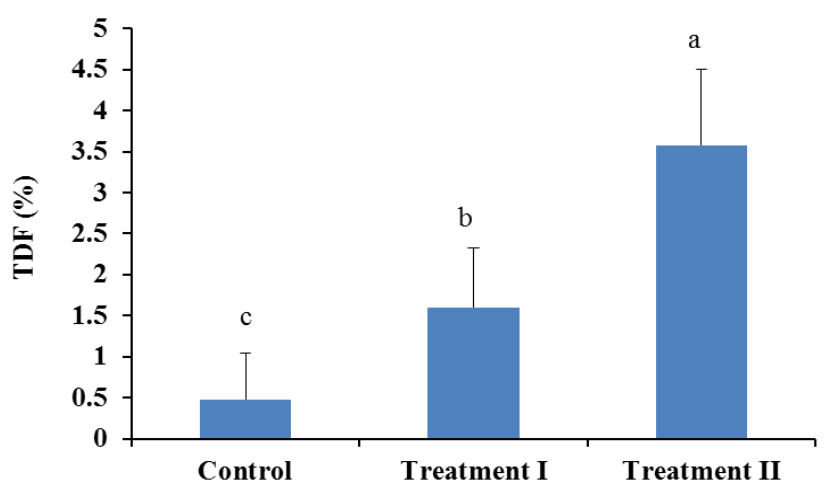

Figure 3. Total dietary fibre (TDF) in sheep meat nuggets. content (Figure 3) and total phenolics (Figure 4) at each level. According to Gorinstein et al. (1999) guava is rich source of polyphenols (4.79 to $5.11 \mathrm{mg} / 100 \mathrm{~g}$ fresh fruit) and dietary fibre (5.14 to $6.04 \%$ on fresh basis) and could be preferable for dietary prevention of atherosclerosis. Dietary fibres in foods are also beneficial for good health. Physiological impacts of insufficient dietary fibre intake are constipation, increased risk of coronary heart disease, and increased fluctuation of blood glucose and insulin levels (Jenkins et al., 1998). Including fruits and vegetables in the human diet may be beneficial, based on their dietary fibre content, with regard to some cancers (Harris and Ferguson, 1993).

\section{Instrument colour parameter}

The effect of guava powder incorporation on the hunter colour value of sheep meat nuggets is presented in Table 4. Though, hunter lightness and yellowness values did not affect significantly, incorporation of guava powder significantly improved the product redness value. This

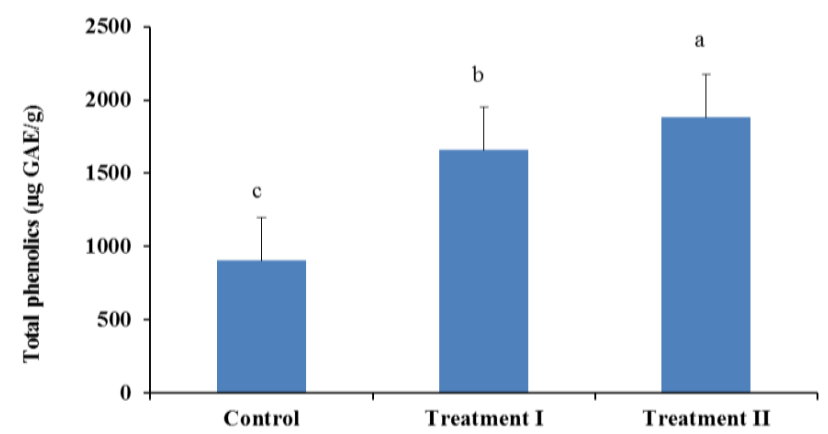

Figure 4. Total phenolics in sheep meat nuggets. 
Table 4. Effect of guava powder on the hunter colour value of sheep meat nuggets

\begin{tabular}{lccl}
\hline Parameters & Control & Treatment I & Treatment II \\
\hline Lightness & $55.08 \pm 0.26$ & $56.39 \pm 0.58$ & $55.40 \pm 0.20$ \\
Redness & $7.87 \pm 0.39^{\mathrm{b}}$ & $8.25 \pm 0.11^{\mathrm{b}}$ & $10.87 \pm 0.85^{\mathrm{a}}$ \\
Yellowness & $14.42 \pm 0.70$ & $12.32 \pm 0.48$ & $13.87 \pm 0.81$ \\
\hline
\end{tabular}

Control $=$ Sheep meat nuggets without guava powder.

Treatment I = Sheep meat nuggets with $0.5 \%$ guava powder.

Treatment II $=$ Sheep meat nuggets with $1.0 \%$ guava powder.

Means bearing different superscripts in a row differ significantly $(\mathrm{p}<0.05)$; $\mathrm{n}=9$.

indicates that addition of guava powder in sheep meat nuggets improved its appearance. According to Verma et al. (2010) redness value of low salt, low fat chicken nuggets significantly improved due to incorporation of apple pulp. A significant increase $(\mathrm{p}<0.05)$ in redness value of bologna sausages incorporated with 7.5 and $10 \mathrm{~g} / 100 \mathrm{~g}$ cooked lemon albedo was reported (Fernandez-Gines et al., 2004).

\section{Texture profile analysis}

The textural property of sheep meat nuggets with guava powder is presented in Table 5. Incorporation of guava powder significantly decreased $(\mathrm{p}<0.05)$ the springiness of the product. Hardness, adhesiveness, cohesiveness, gumminess and chewiness values were not significantly affected $(p>0.05)$ by the addition of guava powder. However these values except cohesiveness were nonsignificantly decreased with added guava powder. A decrease in the hardness value of Chinese style meatballs was reported with increasing levels of bacterial cellulose (Lin and Lin, 2004). Similar results were also observed in low fat, high dietary fibre frankfurters and low fat dry fermented sausages incorporated with peach dietary fibre suspension and cereals, respectively (Grigelmo-Miguel et al., 1999; Dominguez et al., 2002). The present finding was also in accordance with the findings of Verma et al. (2009) who have reported decrease in the textural properties of low salt, low fat chicken nuggets incorporated with high fibre ingredients. The product with guava powder had lower shear force value and work of shear as compared to the
Table 6. Effect of guava powder on the sensory characteristics of sheep meat nuggets

\begin{tabular}{|c|c|c|c|}
\hline Parameters & Control & Treatment I & Treatment II \\
\hline Appearance & $6.88 \pm 0.15$ & $7.02 \pm 0.20$ & $7.12 \pm 0.07$ \\
\hline Glavour & $6.75 \pm 0.18$ & $6.89 \pm 0.23$ & $6.98 \pm 0.07$ \\
\hline Texture & $6.91 \pm 0.18$ & $6.93 \pm 0.14$ & $6.92 \pm 0.15$ \\
\hline Juiciness & $6.81 \pm 0.26$ & $6.77 \pm 0.24$ & $6.72 \pm 0.25$ \\
\hline $\begin{array}{l}\text { Overall } \\
\text { acceptability }\end{array}$ & $6.90 \pm 0.17$ & $6.95 \pm 0.16$ & $7.06 \pm 0.09$ \\
\hline \multicolumn{4}{|c|}{$\begin{array}{l}\text { Control = Sheep meat nuggets without guava powder. } \\
\text { Treatment I = Sheep meat nuggets with } 0.5 \% \text { guava powder. } \\
\text { Treatment II = Sheep meat nuggets with } 1.0 \% \text { guava powder. } \\
\text { Means bearing different superscripts in a row differ significantly }(\mathrm{p}<0.05 \\
\mathrm{n}=30 \text {. }\end{array}$} \\
\hline
\end{tabular}

control with significant effect $(\mathrm{p}<0.05)$ at $1 \%$ level. The present result could be due to formation of weaker three dimensional network of protein matrix attributed to incorporation of guava powder.

\section{Sensory evaluation}

Incorporation of guava powder in sheep meat nuggets did not significantly affect $(p>0.05)$ the organoleptic properties of the product (Table 6). The appearance and overall acceptability scores of the treated products were not significantly higher than the respective control. Thus, sheep meat nuggets can be enriched with the dietary fibre and phenolic contents through incorporation of guava powder without any significant change in the sensory attributes.

\section{Lipid peroxidation in sheep meat nuggets}

As guava powder demonstrated good antioxidant activity; its efficacy in retarding lipid peroxidation of cooked sheep meat nuggets was examined (Figure 5). Storage period had significant influence on the development of lipid peroxidation in the sheep meat nuggets resulting in an increase of TBARS number during the $15 \mathrm{~d}$ of storage. The guava powder and BHT treatments significantly $(p<0.05)$ reduced the TBARS number compared with control throughout the storage except $0 \mathrm{~d}$. The increase in TBARS number in guava powder treated samples was very

Table 5. Effect of guava powder on the texture profile analysis of sheep meat nuggets

\begin{tabular}{lccc}
\hline Parameters & Control & Treatment I & Treatment II \\
\hline Hardness $\left(\mathrm{N} / \mathrm{cm}^{2}\right)$ & $58.04 \pm 2.12$ & $59.18 \pm 2.02$ & $53.62 \pm 3.09$ \\
Adhesiveness (Ns) & $-0.07 \pm 0.03$ & $-0.05 \pm 0.03$ & $-0.04 \pm 0.01$ \\
Springiness (cm) & $0.75 \pm 0.02^{\mathrm{a}}$ & $0.73 \pm 0.02^{\mathrm{a}}$ & $0.63 \pm 0.03^{\mathrm{b}}$ \\
Cohesiveness (ratio) & $0.29 \pm 0.01$ & $0.29 \pm 0.01$ & $0.31 \pm 0.01$ \\
Gumminess $\left(\mathrm{N} / \mathrm{cm}^{2}\right)$ & $17.13 \pm 0.78$ & $17.47 \pm 1.00$ & $16.50 \pm 1.26$ \\
Chewiness $\left(\mathrm{N} / \mathrm{cm}^{2}\right.$ & $12.94 \pm 0.77$ & $12.80 \pm 0.94$ & $10.60 \pm 1.25$ \\
Shear force $\left(\mathrm{N} / \mathrm{cm}^{2}\right)$ & $8.04 \pm 1.10^{\mathrm{a}}$ & $7.25 \pm 0.43^{\mathrm{a}}$ & $4.40 \pm 0.79^{\mathrm{b}}$ \\
Work of shear (Ns) & $4.69 \pm 0.57^{\mathrm{a}}$ & $4.04 \pm 0.15^{\mathrm{a}}$ & $2.39 \pm 0.38^{\mathrm{b}}$ \\
\hline
\end{tabular}

Control = Sheep meat nuggets without guava powder. Treatment I = Sheep meat nuggets with $0.5 \%$ guava powder.

Treatment II $=$ Sheep meat nuggets with $1.0 \%$ guava powder. Means bearing different superscripts in a row differ significantly $(\mathrm{p}<0.05) ; \mathrm{n}=9$. 


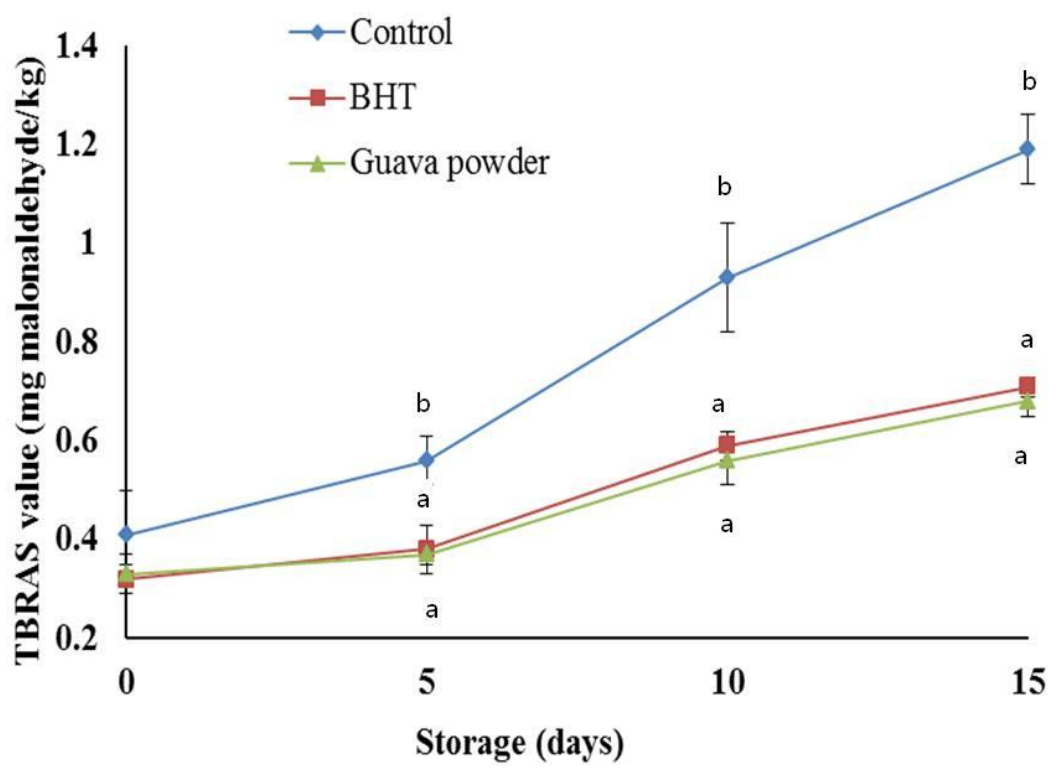

Figure 5. Effect of guava powder $(1 \%)$ incorporation on the TBARS number of sheep meat nuggets stored at $4^{\circ} \mathrm{C}$. Means with the different letter $(\mathrm{a}, \mathrm{b}$ or $\mathrm{c})$ are significantly different $(\mathrm{p}<0.05)$.

slow and remained lowest $(0.68 \mathrm{mg}$ malonaldehyde/kg sample) up to $15 \mathrm{~d}$. Cooked sheep meat nuggets containing guava powder had $40 \%$ less TBARS number than the corresponding sample not containing powder on $\mathrm{d} 15$. Over the storage period, a $37 \%$ reduction was obtained in cooked sheep meat nuggets with guava powder. Thus, the efficacy of guava powder in retarding oxidative rancidity in cooked sheep meat samples was evident and comparable to that of BHT. Recently, Das et al. (2012) observed that the Moringa oleiferia leaves extract was more effective than BHT for preventing increased TBARS number of precooked goat meat patties during storage. The phenolics compounds present in the guava powder may be the reason for its strong antioxidant ability. The data indicated that the marked antioxidant activity of guava powder seems to be the result of their radical scavenging activity and reducing power.

\section{CONCLUSIONS}

The results of the present study exhibited that guava powder is a rich source of dietary fibre, most of which present in an insoluble form and also possesses great antioxidant potential such as radical scavenging activity and ferric reducing antioxidant power. Guava powder is also rich source of phenolic compounds (44.04 mg GAE/g). Incorporation of guava powder significantly affected the physicochemical properties of the products. Most significant effect of guava powder addition in sheep meat nuggets is enrichment of the products with dietary fibre and phenolic compounds. Guava powder improved the redness value of the product thus its appearance. Incorporation of guava powder could protect cooked sheep meat nuggets against lipid oxidation during refrigerated storage. Incorporation of guava powder up to one percent level did not affect products organoleptic attributes. Thus guava powder can be used as a source of antioxidant dietary fibre in sheep meat nuggets without affecting their acceptability.

\section{ACKNOWLEDGEMENTS}

This work was financially supported by the Ministry of Food Processing Industries (MoFPI), New Delhi, India. The authors thank Radhey Shyam, SP Singh and Riyaz Qureshi for their help during the research work.

\section{REFERENCES}

Amarowicz, R., R. Pegg, P. Rahimi-Moghaddam, B. Barl and J. Weil. 2004. Free-radical scavenging capacity and antioxidant activity of selected plant species from the Canadian prairies. Food Chem. 84:551-562.

AOAC. 1995. Official methods of analysis. 16th edn. Association of Official Analytical Chemists, Washington DC, USA.

Bourne, M. C. 1978. Texture profile analysis. Food Technol. 32: 62-72.

Chastain, M., D. Huffman, W. Hsieh and J. Cordray. 1982. Antioxidants in restructured beef/pork steaks. J. Food Sci. 47: 1779-1782.

Cheb, C. W. E. N. and C. H. I. T. Ho. 1995. Antioxidant properties of polyphenols extracted from green and black teas. J. Food Lipids 2:35-46.

Chen, C., A. Pearson, J. Gray, M. Fooladi and P. Ku. 1984. Some factors influencing the nonheme iron content of meat and its implications in oxidation. J. Food Sci. 49:581-584.

Claus, J. and M. Hunt. 1991. Low-fat, high added-water bologna formulated with texture-modifying ingredients. J. Food Sci. 
56:643-647.

Corrêa, L. C., C. A. F. Santos, F. Vianello and G. P. P. Lima. 2011. Antioxidant content in guava (Psidium guajava) and araca (Psidium spp.) germplasm from different Brazilian regions. Plant Genet. Resour. 9:384-391.

Da Porto, C., S. Calligaris, E. Celotti and M. C. Nicoli. 2000. Antiradical properties of commercial cognacs assessed by the DPPH test. J. Agric. Food Chem. 48:4241-4245.

Das, A. K., V. Rajkumar, A. K. Verma and D. Swarup. 2012. Moringa oleiferia leaves extract: a natural antioxidant for retarding lipid peroxidation in cooked goat meat patties. Int. J. Food Sci. Technol. 47:585-591.

Das, A. K. and R. B. Sharma. 2009. Effect of fluid goat milk whey on some quality characteristics of chevon nuggets. Ital. J. Food Sci. 21:81-88.

Decker, E. A., W. K. M. Chan, S. A. Livisay, D. A. Butterfield and C. Faustman. 1995. Interactions between carnosine and the different redox states of myoglobin. J. Food Sci. 60:1201-1204.

Dillard, C. J. and J. B. German. 2000. Phytochemicals: nutraceuticals and human health. J. Sci. Food Agric. 80:17441756.

Dominguez, R., M. Galvez, C. Casas and M. Selgas. 2002. Utilization of cereal and fruit fibres in low fat dry fermented sausages. Meat Sci. 60:227-236.

Eastwood, M. A. 1992. The physiological effect of dietary fibre: an update. Ann. Rev. Nutr. 12:19-35.

Escarpa, A. and M. González. 2001. Approach to the content of total extractable phenolic compounds from different food samples by comparison of chromatographic and spectrophotometric methods. Anal. Chim. Acta. 427:119-127.

Fargere, T., M. Abdennadher, M. Delmas and B. Boutevin. 1995. Determination of peroxides and hydroperoxides with 2, 2diphenyl-1-picrylhydrazyl (DPPH). Application to ozonized ethylene vinyl acetate copolymers (EVA). Eur. Polym. J. 31: 489-497.

Fernandez-Gines, J. M., J. Fernandez-Lopez, E. Sayas-Barbera, E. Sendra and J. A. Perez-Alvarez. 2004. Lemon albedo as a new source of dietary fiber: Application to bologna sausages. Meat Sci. 67:7-13.

Gorinstein, S., M. Zemser, R. Haruenkit, R. Chuthakorn, F. Grauer, O. Martin-Belloso and S. Trakhtenberg. 1999. Comparative content of total polyphenols and dietary fiber in tropical fruits and persimmon. J. Nutr. Biochem. 10:367-371.

Grigelmo-Miguel, N., Abadías-Serós, M. A. I. and O. MartínBelloso. 1999. Characterisation of low-fat high-dietary fibre frankfurters. Meat Sci. 52:247-256.

Halliwell, B. 1996. Antioxidants in human health and disease. Ann. Rev. Nutr. 16:33-50.

Harris, P. J. and L. R. Ferguson. 1993. Dietary fibre: its composition and role in protection against colorectal cancer. Mutat. Res. 290:97-110.

Huang, S., C. Shiau, T. Liu, C. Chu and D. Hwang. 2005. Effects of rice bran on sensory and physico-chemical properties of emulsified pork meatballs. Meat Sci. 70:613-619.

Huang, S., Y. Tsai and C. Chen. 2011. Effects of wheat fiber, oat fiber, and inulin on sensory and physico-chemical properties of chinese-style sausages. Asian Australas. J. Anim. Sci. 24:875880 .
Jenkins, D. J. A., C. W. C. Kendall and T. P. P. Ransom. 1998. Dietary fiber, the evolution of the human diet and coronary heart disease. Nutr. Res. 18:633-652.

Jiménez-Escrig, A., I. Jiménez-Jiménez, C. Sánchez-Moreno and F. Saura-Calixto. 2000. Evaluation of free radical scavenging of dietary carotenoids by the stable radical 2, 2-diphenyl-1picrylhydrazyl. J. Sci. Food Agric. 80:1686-1690.

Jiménez-Escrig, A., M. Rincón, R. Pulido and F. Saura-Calixto. 2001. Guava fruit (Psidium guajava L.) as a new source of antioxidant dietary fiber. J. Agric. Food Chem. 49:5489-5493.

Johnson, I. T. and D. A. T. Southgate. 1994. Dietary fibre and related substance. In: Food Safety Series (Ed. J. Edelman and S. Miller). Chopman and Hall London. pp. 39-65.

Keeton, J. T. 1983. Effect of fat and $\mathrm{NaCl} /$ phosphate levels on the chemical and sensory properties of pork patties. J. Food Sci. 48:878-881.

Kritchevsky, D. 2000. Dietary fiber in health and disease. In: 1st Int. Conf. Dietary Fiber (Ed. B. V. McCleary and L. Prosky) (pp. 38). Dublin, Ireland: Blackwell Science, Oxford, UK.

Lin, K. W. and H. Y. Lin. 2004. Quality characteristics of Chinesestyle meatball containing bacterial cellulose (Nata). J. Food Sci. 69:107-111.

Luximon-Ramma, A., T. Bahorun and A. Crozier. 2003. Antioxidant actions and phenolic and vitamin $\mathrm{C}$ contents of common Mauritian exotic fruits. J. Sci. Food Agric. 83:496502.

Mahattanatawee, K., J. A. Manthey, G. Luzio, S. T. Talcott, K. Goodner and E. A. Baldwin. 2006. Total antioxidant activity and fiber content of select Florida-grown tropical fruits. J. Agric. Food Chem. 54:7355-7363.

Mendoza, E., M. Garcia, C. Casas and M. Selgas. 2001. Inulin as fat substitute in low fat, dry fermented sausages. Meat Sci. 57: 387-393.

Mercadante, A. Z., A. Steck and H. Pfander. 1999. Carotenoids from guava (Psidium guajava $\mathrm{L}$ ): isolation and structure elucidation. J. Agric. Food Chem. 47: 145-151.

Miean, K. H. and S. Mohamed. 2001. Flavonoid (myricetin, quercetin, kaempferol, luteolin, and apigenin) content of edible tropical plants. J. Agric. Food Chem. 49:3106-3112.

Misra, K. and T. Seshadri. 1968. Chemical components of the fruits of Psidium guava. Phytochemistry 7:641-645.

Nahar, N., S. Rahman and M. Mosihuzzaman. 1990. Analysis of carbohydrates in seven edible fruits of Bangladesh. J. Sci. Food Agric. 51:185-192.

Oyaizu, M. 1986. Studies on products of the browning reaction. Antioxidative activities of browning reaction products prepared from glucosamine. Jap. J. Nutr. 44:307-315.

Renaud, S. C., R. Guéguen, J. Schenker and A. d'Houtaud. 1998. Alcohol and mortality in middle-aged men from eastern France. Epidemiology 184-188.

Robards, K., P. D. Prenzler, G. Tucker, P. Swatsitang and W. Glover. 1999. Phenolic compounds and their role in oxidative processes in fruits. Food Chem. 66:401-436.

Sato, K. and G. R. Hegarty. 1971. Warmed-over flavor in cooked meats. J. Food Sci. 36:1098-1102.

Saura-Calixto, F. 2011. Dietary fiber as a carrier of dietary antioxidants: An essential physiological function. J. Agric. Food Chem. 59:43-49. 
Singleton, V. L. and J. A. J. Rossi. 1965. Colorimetry of total phenolics with phosphomolybdic-phosphotungstic acid reagents. Am. J. Enol. Vitic. 16:144-158.

Temple, N. J. 2000. Antioxidants and disease: more questions than answers. Nutr. Res. 20:449-459.

Thaipong, K., U. Boonprakob, K. Crosby, L. Cisneros-Zevallos and D. Hawkins Byrne. 2006. Comparison of ABTS, DPPH, FRAP, and ORAC assays for estimating antioxidant activity from guava fruit extracts. J. Food Compost. Anal. 19:669-675.

Trout, E. S., M. C. Hunt, D. E. Johnson, J. R. Clans, C. L. Castner and D. H. Kropf. 1992. Characteristics of low fat ground beef containing texture modifying ingredients. J. Food Sci. 57:1924.

Verma, A. K. and R. Banerjee. 2010. Dietary fibre as functional ingredient in meat products: a novel approach for healthy living - a review. J. Food Sci. Technol. 47:247-257.

Verma, A. K., R. Banerjee and B. D. Sharma. 2012. Quality of low fat chicken nuggets: Effect of sodium chloride replacement and added chickpea (Cicer arietinum L.) hull flour. AsianAustralas. J. Anim Sci. 25:291-298.
Verma, A. K., B. D. Sharma and R. Banerjee. 2010. Effect of sodium chloride replacement and apple pulp inclusion on the physico-chemical, textural and sensory properties of low fat chicken nuggets. LWT-Food Sci. Technol. 43:715-719.

Verma, A. K., B. D. Sharma and R. Banerjee. 2009. Quality characteristics and storage stability of low fat functional chicken nuggets with salt substitute blend and high fibre ingredients. Fleischwirt. Int. 24:52-57.

Witte, V. C., G. F. Krause and M. F. Bailey. 1970. A new extraction method for determining 2-thiobarbituric acid values of pork and beef during storage. J. Food Sci. 35:582-585.

Y1lmaz, I. 2005. Physicochemical and sensory characteristics of low fat meatballs with added wheat bran. J. Food Eng. 69: 369-373.

Yilmaz, I. and O. DaglIoglu. 2003. The effect of replacing fat with oat bran on fatty acid composition and physicochemical properties of meatballs. Meat Sci. 65:819-823. 